\title{
SAMORZĄD TERYTORIALNY W OCZACH SOCJOLOGÓW - DYSKUSJA
}

Wyniki ostatnich wyborów prezydenckich i parlamentarnych w Polsce doprowadziły do sytuacji, w której zwycięskie środowisko, skupione wokół Prawa i Sprawiedliwości, zyskało możliwość realizowania swojej wizji politycznej bez konieczności zawierania koalicji rządzącej i z życzliwościa, wywodzącego się z tego samego środowiska, prezydenta. Zarówno kształt przedmiotowy wprowadzanych przez nowe władze rozwiązań, jak i formuła ich wdrażania wzbudziły liczne kontrowersje i zdecydowany sprzeciw opozycji (nie tylko parlamentarnej). Jedną z osi sporu stały się proponowane zmiany zwiazane $\mathrm{z}$ funkcjonowaniem samorządów terytorialnych, w tym między innymi - podchwycona przez opinię publiczna, choć w istocie nienowa - propozycja ograniczenia liczby kadencji sprawowania władzy w gminach przez wójtów, burmistrzów i prezydentów. Konsekwencją tej i innych zapowiedzi stała się intensyfikacja debaty publicznej dotyczącej kształtu systemu samorządu terytorialnego w Polsce, kierunków jego przebudowy oraz ewentualnych zagrożeń związanych z realizacją planów ugrupowania rządzącego.

Aby dyskusję dotyczącą kondycji i przyszłości samorządności terytorialnej w Polsce wzbogacić o interpretację socjologiczna, zwróciliśmy się do wybranych badaczy z prośba o przedstawienie ich spostrzeżeń na temat sytuacji samorządności terytorialnej w Polsce. Wypowiedzi w tym swoistym sondażu, które prezentujemy niżej, zostały ukierunkowane trzema pytaniami:

1. Jak ocenić bilans polskiej reformy samorządowej, uwzględniając w szczególności jej społeczne konsekwencje?

2. Jakie są obecnie najważniejsze problemy w funkcjonowaniu systemu samorządu terytorialnego w Polsce?

3. Jak ocenia Pan/i przebieg debaty na temat proponowanych zmian w funkcjonowaniu samorządów terytorialnych, która zintensyfikowała się ostatnimi czasy? Czy jest to debata potrzebna?

Nadesłane stanowiska, do których dodano także wypowiedzi współinicjatorów przedsięwzięcia, prezentujemy w pełnym brzmieniu, bez redaktorskich ingerencji, nie podejmując też próby ich reinterpretacji czy pogłębionej analizy. Traktujemy je jako autonomiczne wypowiedzi, będące wyrazem wiedzy i doświadczenia Autorów, ich głosem w jakże potrzebnej dyskusji. Co do jej zasadności zgodziliśmy się zresztą wszyscy, podobnie jak w odniesieniu do pozytywnej oceny doświadczeń polskiej samorządności. Jednocześnie jednak trudno nie dostrzegać, że funkcjonowanie samorządu terytorialnego w Polsce jest obarczone szeregiem niedoskonałości, barier i wyzwań rozwojowych. Część z nich powtarzała się zreszta. Problem podmiotowości i partycypacji mieszkańców (na który socjolodzy, co dość oczywiste, zdają się szczególnie wyczuleni), bariery prawne i finansowe, trudne - potencjalnie i realnie konflikto- 
genne - relacje pomiędzy poziomami jednostek samorządu i władzy centralnej, to niektóre z nich. Wypracowanie i wdrożenie satysfakcjonujących rozwiązań wymaga współudziału wielu aktorów. Głos ekspertów, przedstawicieli świata nauki winien być również co najmniej dostrzeżony.

Serdecznie dziękujemy Koleżance i Kolegom za „podjęcie rękawicy” i zabranie głosu w dyskusji, jednocześnie pozwalamy sobie potraktować ten materiał jako zaproszenie do dyskusji, do której inspirację znajdą Czytelnicy w niniejszym zeszycie „Ruchu Prawniczego, Ekonomicznego i Socjologicznego” poświęconym polskiej samorządności.

dr hab. Marek Nowak Uniwersytet im. Adama Mickiewicza w Poznaniu kawon.m@amu.edu.pl dr Pawet Śliwa Uniwersytet im. Adama Mickiewicza w Poznaniu p.sliwa@amu.edu.pl

\section{GLOS PIERWSZY ${ }^{1}$ - MAREK S. SZCZEPAŃSKI ${ }^{2}$}

Reforma gminna, w powszechnej ocenie, jest najbardziej udanym przedsięwzięciem reformatorskim okresu transformacji Rzeczpospolitej. Obecnie jesteśmy świadkami nie tyle wielkich inwestycji w gminach, ile bardziej „,poprawiania" małych ojczyzn i niewielkich inwestycji, ułatwiających warunki życia mieszkańcom. Budżety partycypacyjne to nowe zjawisko, angażujące i mobilizujące dużą liczbę obywateli. Ujawniły się i okrzepły w dojrzałej już formie ruchy miejskie i prywatnoojczyźniane. Komplementując reformę, trudno jednak nie zauważyć daleko idącego upartyjnienia lokalnych elit. Ich przeciwwaga starają się być silne komitety lokalne i liderzy - często gwiazdy socjometryczne. Samorząd terytorialny w RP potyka się wciąz z bardzo licznymi wyzwaniami w funkcjonowaniu. Najważniejszym problemem, w moim przekonaniu, jest centralizacja finansów i niedoszacowanie zadań cedowanych na samorządy. Mówiąc wprost, mamy do czynienia z decentralizacją zadań i centralizacją zasobów finansowych. Towarzyszy temu niepewność prawna i częste nowelizacje ustaw regulujących funkcjonowanie samorządów. Trudno też nie zauważyć niepokojącego zjawiska recentralizacji zadań, a dobrych przykładów dostarczają tutaj fundusz ochrony środowiska i planowana reforma urzędów pracy. Warto też podkreślić brak spójnych i dostosowanych do lokalnych warunków zadań rozwojowych.

Często zadania te są klonem priorytetów definiowanych przez Unię Europejska. Oczywiście lokalne samorządy silnie są uzależnione „od kroplówki finansowej” Wspólnoty i rządu RP. Jednocześnie towarzyszy temu przenoszenie politycznych sporów z ulicy Wiejskiej na sceny lokalne. Tym samym brakuje poważnej dyskusji o rozwoju prywatnoojczyźnianym. Nierzadko takie debaty zastępuja polityczne kłótnie, niekiedy o błahym podłożu. Debata

\footnotetext{
1 Autor nadał swojemu stanowisku tytuł: „Restytucja i poprawianie małych ojczyzn”.

${ }^{2}$ Uniwersytet Śląski w Katowicach.
} 
o funkcjonowaniu samorządów sprowadzona została tak naprawdę do sporów o dwukadencyjność wójtów, burmistrzów i prezydentów. Tym samym dialog toczy się wokół kwestii, kto personalnie rządzi na poziomie lokalnym i jak długo, a nie jak zarządza. Nie pojawił się też w tych dyskusjach wątek dotyczący skuteczności samorządu, której miarą może być zaspokojenie potrzeb mieszkańców i częściowa przynajmniej ich mobilizacja.

Odrębna zgoła kwestia jest ustawa metropolitalna, funkcjonująca od 1 lipca 2017 r. Dotyczy wprawdzie jednej tylko części Polski, mianowicie Metropolii Ślasko-Zagłębiowskiej, ale w jej granicach mieszka 2,3 mln ludzi. Funkcjonowanie ślaskiej metropolis ma pilotażowy charakter, gdyż najprawdopodobniej w najbliższych latach pojawią się komplementarne ustawy dotyczące innych aglomeracji miejskich. Podsumowując, można zacytować nieśmiertelne zdanie Alexisa de Tocqueville'a z tomu $O$ demokracji $w$ Ameryce. $\mathrm{Z}$ pewną doza przesady stwierdził on, że człowiek stworzył monarchie i republiki, a gmina pochodzi wprost od Boga.

\section{GŁOS DRUGI - TOMASZ PIRÓG ${ }^{3}$}

Reforma samorządowa stała u podwalin współczesnej Polski. Oddelegowała realną władzę w ręce społeczności lokalnych. U jej podstaw stało założenie mówiące, iż władza powinna być jak najbliżej obywateli, a administracja samorządowa nie powinna zarządzać sprawami lokalnymi bez podmiotowego traktowania mieszkańców gmin. Z perspektywy ostatnich 27 lat widać, jak wiele zawdzięczamy nie tylko ustawom regulującym funkcjonowanie samorządów, ale również oddolnemu duchowi samorządności, który występuje w Polsce. Władze lokalne wykazały dużą sprawność w gospodarowaniu mieniem i rozwiązywaniu lokalnych problemów społecznych. Skutecznie pozyskiwały dotacje unijne i podnosiły poziom życia mieszkańców.

Dzięki konstytucji i ustawom samorządowym powstało pole do działań politycznych, które cechuje autonomia względem rządu. Zjawisko to chroni demokrację liberalną jako system polityczny w kraju. Pozwala bowiem utrzymać pluralizm światopoglądowy $\mathrm{w}$ warunkach konfliktu politycznego. Ponadto w samorządach politycy uczą się sprawnego działania, współdziałania z obywatelami, budowania struktur politycznych i rozwiązywania problemów lokalnych, które dotyczą rzeczywistych potrzeb mieszkańców.

Opisując samorządy, trzeba też wspomnieć o pewnych niedociagnięciach. Jednak ich opis przysparza wiele problemów. Szukając niedociagnięć, szukamy zwykle winnych. W badaniu procesów instytucjonalnych wina często bywa rozmyta, ponieważ deficyty funkcjonowania administracji samorządowej nie muszą wynikać wyłącznie $\mathrm{z}$ wadliwego prawa. Instytucje społeczne swoja skuteczność lub ewentualną nieskuteczność zawdzięczają również czynnikom społecznym (strukturalnym i kognitywnym).

Z perspektywy czasu można stwierdzić, że pozaprawne ograniczenia rozwoju samorządności terytorialnej odgrywały w Polsce istotna rolę. Warto

\footnotetext{
${ }^{3}$ Akademia Górniczo-Hutnicza w Krakowie.
} 
przeanalizować to na przykładzie komunikacji władz lokalnych z obywatelami i współpracy z organizacjami pozarządowymi. W trakcie transformacji systemowej obserwowaliśmy brak gotowości władz lokalnych do tworzenia poliarchicznych wzorów rządzenia oraz nieumiejętność obywateli w zakresie lokalnej artykulacji interesów zbiorowych i samoorganizacji w ramach III sektora. W efekcie powstawała przepaść między rządzonymi i rządzącymi, która sprawiała, że lokalne elity polityczne uzależniały się od centralnych ugrupowań politycznych. Zjawiska te słabły jednak z upływem czasu. Obecnie w polskich gminach widzimy renesans aktywności obywatelskiej, który objawia się wzrostem znaczenia lokalnych komitetów wyborczych i zaangażowaniem obywateli $\mathrm{w}$ ruchy społeczne ( $\mathrm{w}$ dużych miastach pojawiła się ponadto moda na budżety obywatelskie i procesy konsultacyjne). Nie bez znaczenia dla tych procesów był napływ środków unijnych do samorządów, które dzięki temu zyskały większą swobodę finansową. Wzmocniło to pozycję lokalnych elit rządzących względem rządu, a wśród mieszkańców podniosło poczucie obywatelskiego sprawstwa. W efekcie końcowym Polacy lepiej oceniają samorządy niż władze centralne.

Nie sposób jednak zapomnieć, że niektóre zmiany odblokowujące potencjał polskiej samorządności było wymuszane odgórnie. Działo się tak, ponieważ autonomia decyzyjna posiadana przez samorzady w ramach ładu prawnego nie skutkowała generowaniem uchwał, które optymalnie zapewniałby obywatelom poczucie kontrolowania władzy i uczestnictwa w rządzeniu. Co więcej, dopiero zmiany ustawowe narzucane przez sejm były częściowo w stanie odmienić złe wzory rządzenia, które wykształciły się w samorządach m.in. w zakresie udostępniania informacji publicznej, dialogu obywatelskiego i współpracy publicznospołecznej.

Współczesne problemy funkcjonowania systemu samorządu lokalnego najlepiej opisuje publikacja przygotowana przez zespół badawczy pod kierownictwem prof. Jerzego Hausnera ${ }^{4}$. Nie sposób wymienić wszystkich deficytów polskiej samorządności opisanych w tej wyczerpującej publikacji. Dlatego skupię się na jednym wymiarze - partycypacji obywateli w rządzeniu.

Warto tu wymienić dwa zagadnienia osłabiające zaangażowanie obywateli $\mathrm{w}$ demokratyczne procesy decydowania o losie gminy. Po pierwsze w dzisiejszych samorządach w procesach legislacyjnych mamy do czynienia ze słaba pozycją radnych względem wójtów, burmistrzów i prezydentów miast. Fakt ten może szkodzić demokracji lokalnej oraz osłabiać zaangażowanie obywateli w jawne debaty polityczne i przekierowuje dialog obywatelski na tory mniej transparentnych form komunikacji z egzekutywa. Po drugie, istotnym deficytem polskiej demokracji lokalnej są kwestie finansowe. Większość środków, którymi dysponuje samorząd, musi zostać rozdysponowana na zadania ustawowe, i to często według reguł narzuconych przez rząd. Margines wolności $\mathrm{w}$ zakresie kształtowania niektórych polityk publicznych jest niewielki (vide edukacja), a rząd stawia samorządy w trudnej sytuacji, zmuszając je do dopłacania do zadań, które powinny być finansowane z dotacji centralnych. Zja-

${ }^{4}$ J. Hausner et al., Narastajace dysfunkcje, zasadnicze dylematy, konieczne działania. Raport o stanie samorzadności terytorialnej $w$ Polsce, Małopolska Szkoła Administracji Publicznej Uniwersytetu Ekonomicznego w Krakowie, Kraków 2013. 
wisko to ogranicza poczucie obywatelskiego sprawstwa wśród mieszkańców gmin, ponieważ wiele decyzji wykonawczych leży poza zakresem ich kompetencji. Zjawisko to obecnie ma mniejsze znaczenie niż w latach dziewięćdziesiątych XX w., kiedy to zostało opisane przez prof. Zytę Gilowską̧, ponieważ samorządy dysponują zwiększonymi środkami finansowymi pochodzącymi ze środków unijnych. Jednak dostrzeżenie tego problemu jest bardzo ważne dla przyszłości rozwoju polskiej samorządności terytorialnej. Jego waga znów wzrośnie, gdy strumień funduszy unijnych zacznie wysychać. Wówczas gminy z powrotem popadną w większą zależność od ustaw i ograniczeń budżetowych ustalanych w Warszawie.

Od pewnego czasu w mediach zintensyfikowała się debata na temat zmian w funkcjonowaniu samorządów lokalnych. Niestety nie dotyczy ona tylko zarysowanych wcześniej problemów, ale ma także wymiar zorientowany na bieżące cele polityczne. Wśród pozytywnych rozwiązań przemycane sa pomysły, które jawnie uderzają w podstawy konstytucyjnego państwa prawa. Na przykład zakaz pełnienia funkcji wójtów, burmistrzów i prezydentów miast przez więcej niż dwie kadencje można potraktować jako próbę ożywienia demokracji lokalnej i osłabienia silnej pozycji tych aktorów w gminach. Jednak połaczenie jej z założeniem, że prawo będzie działało wstecz, budzi oburzenie wśród zwolenników demokratycznych reguł rządzenia. Podobna sytuacja ma miejsce w propozycji łączenia gmin w szersze byty administracyjne, bez pytania o zdanie ich mieszkańców. Niekiedy takie połączenia moga mieć sens ekonomiczny i administracyjny, ponieważ ułatwiają rozwiązywanie problemów lokalnych. Jednak dla idei samorządności terytorialnej dbałość o sprawność działania administracji samorządowej nie jest najważniejsza. Bliższa jest jej troska o poczucie podmiotowości lokalnej i oddelegowywanie sprawstwa politycznego w ręce obywateli. Wszelkie próby reform administracyjnych bez pytania o zdanie mieszkańców gmin również uderzają w ducha samorządności. Warto o tym pamiętać, zwłaszcza że reforma administracyjna, która powołała do życia gminy, jest jednym z najlepszych skutków polskiej transformacji systemowej (zarówno według ocen ekspertów, jak i obywateli).

\section{GLOS TRZECI - HUBERT KOTARSKI ${ }^{6}$}

Ocena bilansu polskiej reformy samorządowej zbiega się z jej pełnoletnością. Osiemnaście lat od wprowadzenia trójstopniowej struktury podziału terytorialnego kraju pokazało, że mimo wielu emocji i dyskusji związanych $\mathrm{z}$ wprowadzaniem zmian była ta dobra decyzja. Można powiedzieć, że szesnaście województw okrzepło i wrosło w świadomość mieszkańców. Niewątpliwie proces społecznej akceptacji nowego podziału terytorialnego przebiegał szybciej w przypadku województw, które w swej nazwie nawiązywały do historycznej spuścizny podziału terytorialnego Polski. Bardziej długotrwały

${ }^{5}$ Por. Z. Gilowska, Decentralizacja systemu budżetowego jako warunek konieczny zasady subsydiarności, w: D. Milczarek (red.), Subsydiarność, Centrum Europejskie Uniwersytetu Warszawskiego, Warszawa 1998, s. 173-181.

${ }^{6}$ Uniwersytet Rzeszowski. 
proces dotyczył województw, w przypadku których nowa nazwa województwa była całkiem nowa. Tak było w przypadku między innymi województwa podkarpackiego. Niewątpliwie czynnikiem, który wydatnie pomógł województwom stać się regionami, były środki europejskie, których dystrybucję na poziomie regionu powierzono tym właśnie samorządowym jednostkom. Niewątpliwie słabością reformy w perspektywie wojewódzkiej jest utrzymywanie nieco sztucznej dwuwładzy w postaci urzędu wojewódzkiego z wojewodą oraz urzędu marszałkowskiego z marszałkiem województwa. Jak pokazują to badania socjologiczne, dla przeciętnego respondenta podział ten jest niezrozumiały, a codziennościa jest nierozróżnianie tego, kto stoi na czele jakiego urzędu - wojewoda czy marszałek województwa. Niewątpliwie słabością reformy jest również utworzenie dwóch typów powiatów, które również dla przeciętnego obywatela nie sa zrozumiałe. Mowa tu o powiatach ziemskich i miastach na prawach powiatów, określanych również często jako powiaty grodzkie. Miasta na prawach powiatów to pewnego rodzaju wyspy otoczone obszarem, który funkcjonalnie przynależy do nich, ale administracyjnie jest częścią innej jednostki terytorialnej. Widać to bardzo dobrze właściwie w przypadku większości miast na prawach powiatów. Są one realnymi centrami i biegunami wzrostu w mikroskali, które jednak często mają ograniczone możliwości rozwoju przestrzennego. Problem ten obrazuje przykład Rzeszowa, który w chwili wchodzenia w życie reformy był jednym z najmniejszych powierzchniowo miast powyżej 150 tys. mieszkańców. Proces rozszerzania Rzeszowa trwa nieprzerwanie i pokazuje, że bez nowych terenów pod inwestycje i budownictwo mieszkaniowe miasto nie ma szans na rozwój. Rzeszów funkcjonalnie obejmuje obszar znacznie większy niż jego administracyjne granice i trudno nie odnieść wrażenia, że podział na powiat ziemski i grodzki w takich przypadkach jest sztuczny. Podsumowujacc społeczne plusy i minusy reformy samorządowej, wydaje się, że jej największym plusem są bezpośrednie wybory wójtów, burmistrzów i prezydentów miast. Możliwość wyboru konkretnej osoby i społeczna legitymacja do sprawowania urzędu wpłynęły niewątpliwie na fakt, że w badaniach zaufania społecznego do osób publicznych wójtowie, burmistrzowie i prezydenci miast cieszą się relatywnie najwyższym poziomem zaufania.

Wydaje się, że największym problemem są finanse. Widać to szczególnie na poziomie powiatów, które mają najsłabsze umocowanie finansowe, a spora liczbę zadań własnych, które wymagają sporych nakładów finansowych - edukacja, pomoc społeczna. Pewnego rodzaju problemem jest również dwuwładza na poziomie województwa, która jest niezrozumiała dla obywatela, a także często powoduje chaos kompetencyjny i nieefektywne działanie.

Debata na temat funkcjonowania samorządu terytorialnego niewątpliwie jest potrzebna. Niestety brak w niej głosu ekspertów i naukowców zajmujących się tą problematyką. Debata taka, w której uczestniczyliby politycy, przede wszystkim z lokalnego szczebla oraz eksperci naukowcy, przyczyniłaby się może również do pojawieniem się u decydentów świadomości o możliwości skorzystania z wiedzy niezależnych ekspertów i naukowców. Wiedza ta jest nieoceniona pomoca w wdrażaniu polityki rozwoju jednostek samorządu terytorialnego opartej na dowodach (ang. evidence based policy). 


\section{GŁOS CZWARTY - TATIANA MAJCHERKIEWICZ ${ }^{7}$}

W poniższych odpowiedziach ograniczę się do szczebla samorządu województw, na którym koncentrują się moje badania, choć jestem świadoma, że jest to tylko pewien wycinek problemów samorządu w obliczu najbardziej aktualnych zjawisk społeczno-prawnych.

Zmiany, jakie zaszły w samorządzie województw, jak w soczewce oddaja postawy i motywacje marszałków województw. Osoby, które kierowały województwami w pierwszych kadencjach, odwoływały się przede wszystkim do etosu inteligenckiego i potrzeby tworzenia tożsamości regionalnej. Natomiast od 2004 r. ich postawy silnie ewoluują w kierunku takich wartości, jak pragmatyzm; kluczowe stają się umiejętności jak najskuteczniejszego wykorzystania funduszy europejskich.

Jednym z problemów, który warto dostrzec, jest stopniowe osłabienie pozycji sejmików wojewódzkich. Ich rola była stosunkowo duża w dwóch pierwszych kadencjach, co związane było z koniecznością zapewnienia sobie przez zarządy większości sejmikowej. Do 2001 r. zasiadało w nich wielu ważnych polityków regionalnych, pełniących m.in. równocześnie funkcje posłów. W I kadencji duża była też reprezentacja środowisk akademickich.

Sejmiki mają bardzo ograniczony wpływ na decyzje dotyczace wydatkowania funduszy europejskich. Ich pozycję osłabia także wzrost dyscypliny partyjnej wśród radnych. Rozstrzygające w większości sytuacji są preferencje szefów struktur regionalnych partii. Dodatkowo często wielu radnych nie jest zainteresowanych pracą w zarządzie (szczególnie jeżeli zmiany w ich składzie zachodza w trakcie kadencji). Prawomocność tej instytucji jest także ograniczona przez niska frekwencję wyborcza, wysoki odsetek głosów nieważnych, małą wiedzę wyborców o samorządzie województwa oraz „drugorzędność tych wyborów”.

W ostatnich miesiącach w debacie publicznej duże emocje wzbudziła kwestia dwukadencyjności prezydentów, burmistrzów i wójtów. Dane statystyczne wskazuja, że m.in. dokładnie połowa z marszałków pełni swoją funkcję co najmniej od 2010 r., zarazem 4 osoby to marszałkowie co najmniej trzykadencyjni. Podobne trendy dotyczą członków zarządów. Innymi słowy, zjawisko dwukadencyjności dotyczy także regionalnych egzekutyw, a jednak kwestia ta nie została poruszona w debacie publicznej. Obrazuje to szerszy trend; samorząd wojewódzki pozostaje na pewnym uboczu w toczącej się debacie, choć i w jego przypadku zachodzi wiele zjawisk podobnych do tych na szczeblu lokalnym.

\section{GLOS PIĄTY - MAREK NOWAK ${ }^{8}$}

Obecny kształt systemu samorządu terytorialnego w Polsce opiera się na trzech kluczowych reformach - restytucji samorządności terytorialnej w gminach w 1990 r., wdrożeniu od 1999 r. trójszczeblowego zasadniczego podziału

\footnotetext{
7 Uniwersytet Pedagogiczny w Krakowie.

8 Uniwersytet im. Adama Mickiewicza w Poznaniu.
} 
terytorialnego kraju, z powołaniem samorządu na dwóch wyższych szczeblach tej organizacji, wreszcie, zastapieniu kolegialnego organu wykonawczego $\mathrm{w}$ gminie organem jednoosobowym, powoływanym w drodze bezpośrednich wyborów, które po raz pierwszy w tej formule odbyły się w 2002 r. Kształt ustrojowy samorządu został więc ufundowany i utrwalony, a jego funkcjonowanie wyznacza specyfika relacji pomiędzy głównymi aktorami sfery publicznej, w tym kolejnymi poziomami władzy samorządowej (wojewódzkiej, powiatowej i gminnej), administracją państwową oraz społecznościami lokalnymi, które z czasem zyskiwały na znaczeniu, w tym sensie, że ich wpływ wykazywał tendencje do wykraczania poza ustawową formułę reprezentacji czy też jej twórczego rozwijania (chodzi tu choćby o powszechną praktykę konsultacji społecznych i np. realizowane projekty budżetu obywatelskiego). Nie jest w związku z tym przypadkiem, że samorząd terytorialny uchodzi za przykład udanych reform i sukcesu, jednocześnie: decentralizacji i upodmiotowienia obywateli. Można odnieść wrażenie, że podobnego zdania są tu zarówno politycy, jak i mieszkańcy, członkowie lokalnych społeczności (rzecz we współczesnym dyskursie publicznym dość rzadka). Nie oznacza to bynajmniej, że obraz jest tylko jasny, a samorząd jest jak Fukuyamowska teza „o końcu historii”, a zatem „domknięta” i bezalternatywna. Kluczowa kwestia na tym etapie rozwoju samorządności to poziom i jakość zaangażowania obywateli w działania władcze i formy ewaluacji podejmowanych przez władze samorządowe decyzji. W tym zakresie, po etapie instytucjonalizacji i konsolidacji samorządów (jako wyodrębnionych poziomów władzy w nowoczesnym państwie), na pierwszy plan wysuwa się pytanie: jak poprawić poziom zaangażowania obywateli, by sukces mierzony był nie tyle przysłowiowymi tonami wylanego betonu (dzięki środkom pomocowym UE), ile np. przyrostem frekwencji wyborczej, powszechnością udziału w konsultacjach lub też rozpowszechnieniem formuł budżetów partycypacyjnych.

Obecnie wchodzimy w etap generalnych ocen i poszukiwań, co związane jest z radykalną zmiana, jaką przyniosły wyniki ostatnich wyborów parlamentarnych. Nie kwestionując realności problemów wpływających na decyzje Polaków, warto zastanowić się nad wyzwaniami, przed jakimi stoi obecnie samorząd terytorialny. W przekonaniu socjologów zajmujacychch się zagadnieniami wolontariatu i społecznego aktywizmu jest to bez watpienia urealnienie wpływu obywateli na decyzje rozwojowe podejmowane obecnie przez samorządy. Należy w tym zakresie wysoko ocenić tendencje, by w proces decyzyjny wprowadzać formy konsultacji społecznych. Istotna jest jednak nie tylko sama obecność konsultacji, lecz także ich jakość. Tutaj ujawniają się zarówno problemy z umocowaniem konsultacji w procesie podejmowania decyzji (tak by poprawiać jakość podejmowanych decyzji, a nie np. wzbudzać konflikty), z drugiej strony staje się jasne, że w silnie upodmiotowiajacych obywateli samorządach (a tak jest bez wątpienia w Poznaniu, Gdańsku czy Wrocławiu), zaczynamy mieć do czynienia ze swoistym syndromem „przekonsultowania”. Obydwa zjawiska (nieumiejętne posługiwanie się konsultacjami oraz np. zbyt duża ich liczba) są groźne dla samorządności, choć zagrożenia te są innego rodzaju niż dotychczas dostrzegane. Uderzają bowiem w samą istotę podmiotowości obywatelskiej, skłaniając do pytania o funkcjonalność upodmiotowienia. 
Trudno kwestionować potrzebę dyskusji na temat samorządu terytorialnego, tym bardziej że skłaniają do tego przewartościowania, z jakimi spotykamy się ostatnio. To, co wysuwa się na plan pierwszy, to rosnacy brak zaufania. Rola socjologów, czy generalniej badaczy społecznych pytanych o poszczególne kwestie (bądź szczegółowe rozwiązania legislacyjne), jest łagodzenie napięć przez czynienie sporu bardziej racjonalnym. Weberowskie założenie „wolności od wartościowania" wydaje się minimum, jakiego należy oczekiwać od współczesnych badaczy samorządu terytorialnego.

\section{GLOS SZÓSTY - PAWEŁ ŚLIWA ${ }^{9}$}

Pozytywna ocena dokonanej w Polsce reformy samorządowej stała się swego rodzaju aksjomatem debaty publicznej. Trudno zreszta z takim statusem tej oceny polemizować, zwłaszcza jeśli skupić uwagę na uogólnionym obrazie konsekwencji restytuowania instytucji samorządu terytorialnego. Efekty reformy można ujmować w różnych perspektywach. Począwszy od zwrócenia uwagi na ustrojowy przełom, który dokonał się (również) za sprawą przywrócenia samorządności, stanowiącej fundament dawnych i współczesnych demokracji, poprzez skoncentrowanie się na procesach optymalizacji mechanizmów zarządzania, prowadzących do efektywniejszego gospodarowania zasobami pozostajacymi w gestii sektora publicznego, aż po dostrzeżenie konkretnych dokonań poszczególnych samorządów, by wspomnieć tu tylko o inwestycjach infrastrukturalnych czy poprawie estetyki polskich wsi i miast. Dokonania te nie mogły umknaćc uwadze samych mieszkańców, którzy od lat - co pokazują dobitnie wyniki badań opinii społecznej - oceniają reformę samorządową nad wyraz życzliwie.

Sukces odrodzonej samorządności nie byłby możliwy bez społecznego zaangażowania. Z socjologicznej perspektywy jest to zreszta jedna z kluczowych kwestii, ważny element bilansu dokonywanych zmian. Reforma gminna z 1990 r., a później wprowadzenie instytucji samorządu również na wyższych poziomach organizacji administracji terytorialnej nadało podmiotowość zbiorowościom terytorialnym nie tylko w prawnym tego słowa znaczeniu. Zwłaszcza na poziomie gmin, szczególnie w pierwszych latach istnienia lokalnego samorządu, można było zaobserwować znaczny wzrost aktywności części mieszkańców, mocno zaangażowanych w działalność, a właściwie tworzenie, nowo powstałej instytucji. Proces ten nie dotyczył oczywiście wszystkich, ale tego typu oczekiwanie z góry przecież skazane jest na niepowodzenie. Entuzjazm ten nieco później osłabł, choć w ostatnich latach można dostrzec ponowny wzrost zainteresowania aktywnościa na rzecz lokalnych wspólnot. Nieco inaczej, by nie powiedzieć gorzej, przedstawia się społeczne zainteresowanie i gotowość do podejmowania działań na rzecz samorządu powiatowego i (zwłaszcza) wojewódzkiego, co jednak nie jest sytuacją szczególnie zaskakująca, biorąc choćby pod uwagę większe oddalenie tych struktur (w tym symboliczne i subiektywnie postrzegane) od spraw codziennych mieszkańców czy też ich ustrojowa konstrukcję.

\footnotetext{
${ }^{9}$ Uniwersytet im. Adama Mickiewicza w Poznaniu.
} 
Na kwestię obywatelskiego zaangażowania w działalność podejmowana $\mathrm{z}$ udziałem instytucji samorządu czy też $\mathrm{w}$ ich ramach można też spojrzeć z jeszcze innej perspektywy, wskazując tym samym jeszcze jeden element bilansu reformy samorządowej. Przyczyniła się ona bowiem do wykreowania w polskich warunkach nowego, a w państwach o dłuższych tradycjach demokratycznych naturalnego, mechanizmu wyłaniania elit, w tym elit politycznych. Ścieżka kariery, w której pierwsze kroki stawiane są w lokalnym czy wręcz sublokalnym środowisku, a późniejsze w ramach struktur samorządowych coraz wyższych szczebli i wreszcie przybieraja postać zaangażowania w politykę na szczeblu krajowym czy też europejskim, stała się udziałem wielu osób. Oczekuje się przy tym, że wiedza i doświadczenia nabywane w ramach działalności podejmowanej w instytucjach samorządowych będą korzystne nie tylko z punktu widzenia indywidualnych oczekiwań i aspiracji samych osób tą ścieżką podążających, ale także interesu wspólnego. Wszak samorządy zajmują się przede wszystkim (a przynajmniej zajmować się powinny) realnymi i konkretnymi problemami, a nie kwestiami natury ideologicznej. Postawa dobrze pojętego pragmatyzmu, w ten sposób ukształtowana wydaje się zbieżna z oczekiwaniami większości obywateli. Rodzi się jednak oczywiście pytanie, $\mathrm{w}$ jakim stopniu proces rekrutowania i kształtowania elit przebiega w Polsce według zasygnalizowanej i pożądanej logiki. Odpowiedź niekoniecznie jest optymistyczna.

Powszechność opinii o sukcesie polskiej reformy samorządowej niesie ze sobą swoistego rodzaju niebezpieczeństwo. Przywołując potoczne powiedzenie, samorząd terytorialny bywa traktowany jak osoba zmarła, o której mówić należy wyłącznie dobrze albo wcale. Tymczasem funkcjonowanie samorządności terytorialnej w Polsce (jak również poszczególnych jednostek samorządu, traktowanych indywidualnie) obarczone jest szeregiem problemów i barier rozwojowych. Nie sposób ich tutaj wymienić wszystkich, tym bardziej niemożliwe jest ich skrótowe choć omówienie. $\mathrm{Z}$ tego też względu uwaga skoncentrowana zostanie na jednym ogólnym zagadnieniu, z którego wyprowadzić wszakże można (za jego pomoca zinterpretować) szereg problemów ujętych bardziej szczegółowo. Chodzi o instrumentalne traktowanie samorządności terytorialnej przez władze i elity polityczne szczebla centralnego. W państwie zdecentralizowanym to one odpowiadają za ramy, w które wpisana jest instytucja samorządu, określają przedmiot i stopień swobody działania, zakres i formy kontroli oraz nadzoru, kształtuja podział zadań i wzajemne relacje między różnymi poziomami władzy i administracji, wskazują źródła dochodów itp. Czynią to z uwzględnieniem różnorodnych uwarunkowań. Zalicza się też do nich, co oczywiste, choć niekoniecznie optymistyczne, interes polityczny ugrupowań aktualnie sprawujących władzę. Problem pojawia się wówczas, gdy ów interes zaczyna odgrywać rolę dominująca. Prowadzić to może do wdrażania rozwiązań nieracjonalnych i nieuzasadnionych rzeczywistymi potrzebami i warunkami (nie licząc politycznego partykularyzmu), albo zaniechania zmian potrzebnych i odpowiadających panującym uwarunkowaniom. „Duch” samorządności, która przecież przedstawiciele zdecydowanej większości polskich ugrupowań politycznych traktuja jako nieodzowny i potrzebny element 
współczesnego państwa, zepchnięty zostaje na dalszy plan. Upodmiotowienie zbiorowości terytorialnych staje się w tym przypadku niepełne, a ich interes drugorzędny. Upartyjnienie, które często wskazuje się jako jeden z problemów polskiej samorządności, materializuje się nie tylko w logice i mechanizmach funkcjonowania samorządowych organów władzy, ale także w warunkach, które są dla funkcjonowania samorządów tworzone - często w formie przerzucania na nie odpowiedzialności i kosztów wdrażanych (lub zaniechanych) rozwiązań.

Powyższa teza nie jest szczególnie odkrywcza. Raczej też nie powinna budzić kontrowersji. Te pojawić mogą się natomiast, jeśli zaryzykować twierdzenie, że zarysowany mechanizm nie jest stosowany tylko przez niektóre ugrupowania polityczne, lecz „solidarnie” przez wszystkie partie, które w różnym czasie miały swój udział w realnym sprawowaniu władzy na poziomie centralnym. Liczne przykłady takich działań odnaleźć można w różnych okresach po zapoczątkowaniu transformacji systemowej, przy różnych konfiguracjach układów ugrupowań rządzących. Opóźnienie przekazania oświaty w gestię samorządów, zaniechanie kontynuacji reformy samorządowej w połowie lat dziewięćdziesiątych, ukształtowanie struktury nowego podziału na województwa (liczba jednostek) oraz ich ustroju (w tym mechanizmy wyborcze, premiujacee partie polityczne), rozdrobnienie i skromny zakres zadań powiatów - to wybrane przykłady z pierwszej dekady transformacji. W ostatnich latach - tzw. rewolucja śmieciowa, reforma systemu planowania i prowadzenia polityki rozwoju, opóźnienie wprowadzenia systemowych rozwiązań dla największych miast (o które upominali się sami samorządowcy i eksperci) to przykłady niedawne. Aktualnie wdrażana reforma systemu oświaty, żywo dyskutowany projekt ograniczenia kadencyjności wójtów, burmistrzów, prezydentów czy zmiany w zakresie funkcjonowania Regionalnych Izb Obrachunkowych - to z kolei przykłady najświeższe. Wszystkie je można interpretować w kategoriach dominacji interesu partyjnego nad interesami wspólnot samorządowych, choć rzecz jasna nie jest to interpretacja jedyna. Przyjmując ją jednak, dostrzec można, że decyzje i działania o niekoniecznie prosamorządowym wydźwięku były udziałem nie tylko ugrupowań oskarżanych o chęć dokonania destrukcji samorządności, lecz także tych, które przedstawiają się jako jej strażnicy.

Warto wskazać na jeszcze jedną okoliczność. System administracji publicznej, w tym struktury samorządowe jako jego ważny element, należy rozpatrywać w ujęciu dynamicznym. Musi on podlegać zmianom, ponieważ zmieniaja się uwarunkowania, w których funkcjonuje (w tym związane z członkostwem w Unii Europejskiej), oraz potrzeby, które ma zaspokajać. Zmieniaja się też nastroje społeczne oraz polityczne preferencje wyborców. Z tego względu dokonywanie korekt w kształcie obowiąujących rozwiązań należy uznać za rzecz naturalną i oczywistą. Ważne, by uwzględniać przy tym nie tylko jednostronnie ujmowane argumenty.

Nie ulega wątpliwości, że system samorządu terytorialnego wymaga działań usprawniających jego funkcjonowanie i ułatwiajacych rozwiązanie problemów, którymi jest ono obarczone. Z tego punktu widzenia zintensyfikowanie dyskusji na temat przyszłości samorządu, z którą mamy ostatnio do czynienia, 
jest bez wątpienia zjawiskiem pożądanym. Niestety jednak jej przebieg trudno ocenić jako satysfakcjonujący. Radykalizacja sporu politycznego prowadzi do ideologizacji debaty. Mniej ważne wydaje się to, co się mówi, bardziej zaś to, kto mówi. Używane są argumenty przejaskrawione, skrajnie populistyczne, często niepodbudowane empirycznymi dowodami. I dotyczy to obu stron politycznego sporu. W tych okolicznościach rośnie zdecydowanie potrzeba prezentowania stanowisk bardziej merytorycznych, czego oczekiwać należałoby od przedstawicieli środowisk eksperckich, w tym naukowych. Wydaje się jednak, że przynajmniej części z nich udzieliły się polityczne emocje. Byłoby wielką szkoda, gdyby w efekcie zaistniałej sytuacji destrukcji uległ pozytywny wizerunek samorządności terytorialnej, budowany od niemal trzech dziesięcioleci. Szkodą jeszcze większą byłaby destrukcja samej samorządności. Jak jednak wcześniej wskazano, wina za taką ewentualność rozłoży się pomiędzy całkiem liczne grono „podmiotów sprawczych”.

\section{TERRITORIAL SELF-GOVERNMENT IN SOCIOLOGISTS' EYES - A DISCUSSION}

\section{Sum mary}

The last elections in Poland have substantially changed the political discourse. The new government has started to implement numerous reforms. Many of them aroused great controversy, including the one introducing changes in the local government system. This discussion can be considered as an invitation to broader considerations on the future of local government in Poland. It contains statements of six sociologists who are professionally interested in local government issues. They were inspired by three questions (asked by the editors of the text) about: (i) the possible outcome of the reform of the territorial self-government (ii) the functioning of the territorial self-government (iii) the evaluation of the discussion on the announced changes. The answers to these questions were based on the research knowledge and research experiences of the respondents and are therefore more science-based that general opinions typical for a public discussion which often manifest the worldview (or political attitudes) of the debating parties. 